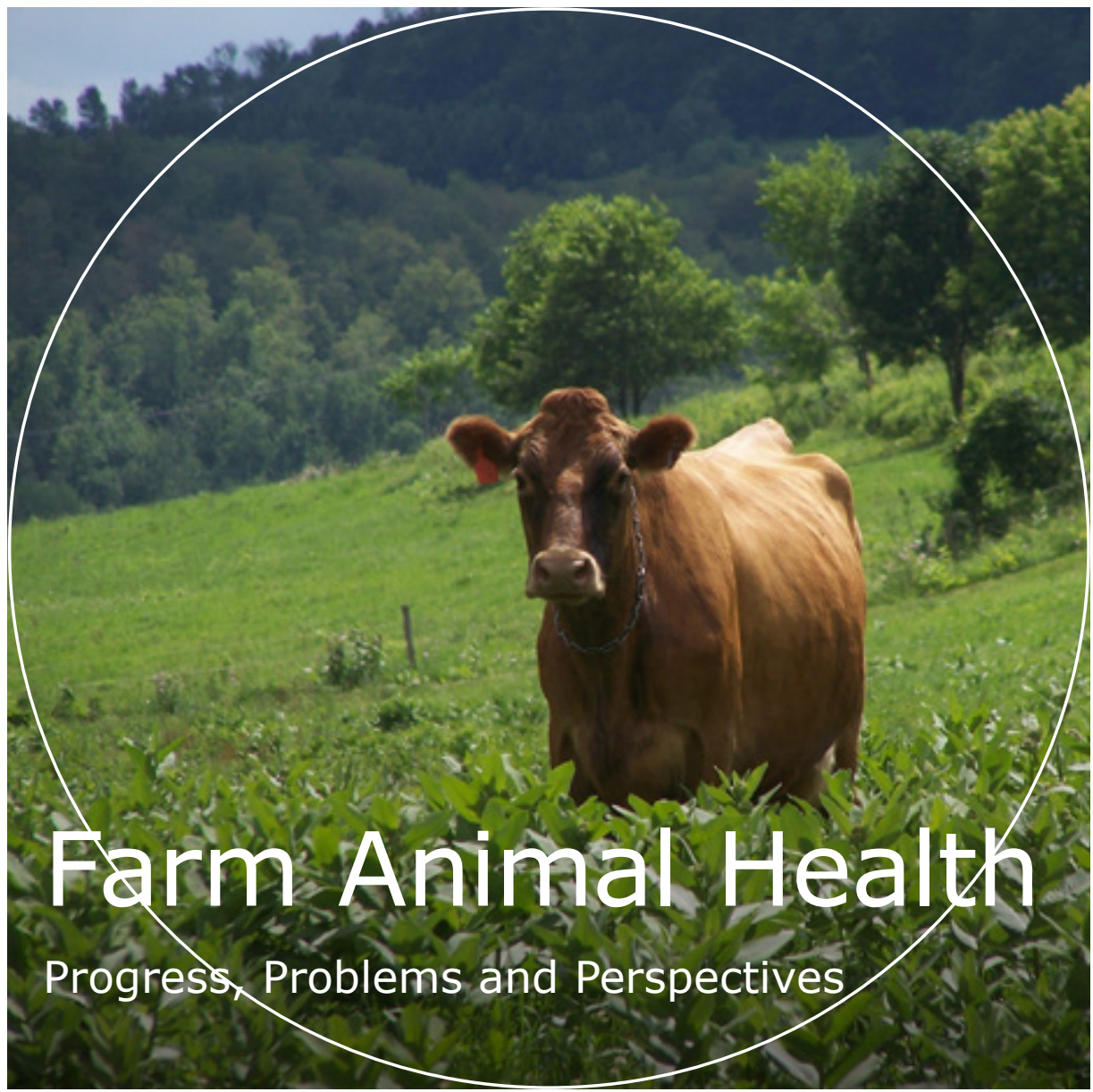

Prof.dr Ynte H. Schukken

Inaugural lecture upon taking up the position of Special Professor of Farm Animal Health at Wageningen University \& Research on 11 May 2017 



\section{Farm Animal Health Progress, Problems and Perspectives}

\section{Prof.dr. Ynte H. Schukken}

Inaugural lecture upon taking up the position of Special Professor of Farm Animal Health at Wageningen University \& Research on 11 May 2017 
DOI HTTPS://DOI.ORG/10.18174/420484

ISBN 978-94-6343-647-2 


\section{Farm Animal Health Progress, Problems and Perspectives}

Esteemed Rector Magnificus, Dear colleagues, students, family and friends,

It is an honour and a pleasure for me to address you all today in this inaugural lecture, I will take you on a tour through the progress, problems and perspectives in farm animal health, with lots of examples, some recent results of my research and will end the lecture today with my research ambitions for the coming years.

\section{Introduction}

However, it is the occurrence of Cattle Plague (or Rinderpest) in the $18^{\text {th }}$ century that started the developments in farm animal health that we discuss today. During the time of the outbreaks of cattle plague, three outbreaks happened in the $18^{\text {th }}$ century in the Netherlands, 1713,1744 and 1768, and the years thereafter, the economy of the affected regions was severely affected. In this research project based in the archives of Oldemarkt, the tax income from the number of cattle on farms was related to the population size and birth rate in the same area. It turned out that during and after the cattle plague outbreaks, tax income from cattle went down and the human population size and birth rate was affected. Both population size and birth rate showed downward trends in the years after the outbreak of cattle plague (Krol 1985). This was true in general in areas where cattle plague ravaged the cattle populations. The devastation was especially present in the areas where more dense populations of cattle were present, in some counties more than $90 \%$ of cattle died and relatively few animals remained unaffected or recovered from the severe clinical signs of this infectious disease.

In the spring of 1985 , I was quite interested in the agricultural and socio-economic history of the village of Oldemarkt. This was not so much because of a genuine interest in "people and peat", it was really because I was doing my very best to impress my then girlfriend who was doing this research (Figure 1). I never dreamed that I would use the results of her study as the start of my inaugural lecture today at Wageningen University and Research. 


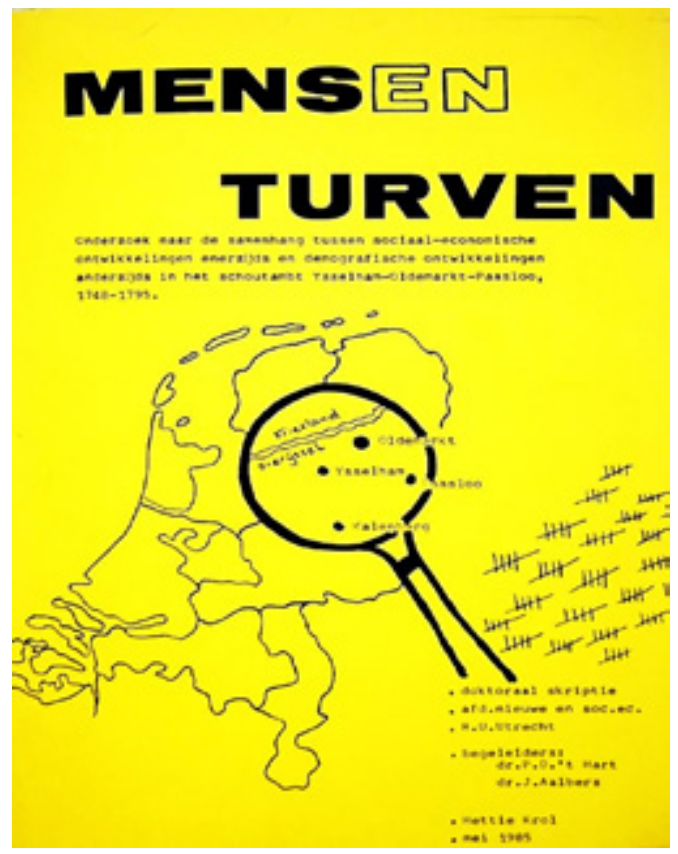

Figure 1. Mensen en Turven, doctoral thesis, H. Krol

In the bookprint from the hand of Jan Smit in 1745 (figure 2), the severe outcome of the cattle plague is shown by the peasants and farmers to the landowner who familiarizes himself with the situation from the comfort of his carriage. The response in the Netherlands to the subsequent outbreaks of cattle plague in the $18^{\text {th }}$ century is now judged as ineffective. For example the measure to increase the number of days of public prayer turned out to be not so effective (Faber 1962). Currently, the Dutch response in the 18th century to cattle plague, in contrast to the use of the so called Lancisi-system that was used across Europe, is seen as an example of how not to deal with infectious disease in cattle (Sundberg, PhD thesis 2015). Even more, it has been argued that the ineffectiveness of dealing with the cattle plague and another series of natural disasters were the cause for the collapse of the Dutch economy and the reason for the end of the golden age in Dutch history (Sundberg 2015).

However, from a more positive perspective, the cattle plagues may also be considered the start of modern veterinary epidemiology and immunology. From the outbreaks of cattle plagues in the different areas in the Netherlands, it became clear that risk factors such as cattle density and biosecurity were major contributors to more severe outbreaks in areas where more of these risk factors were present. 


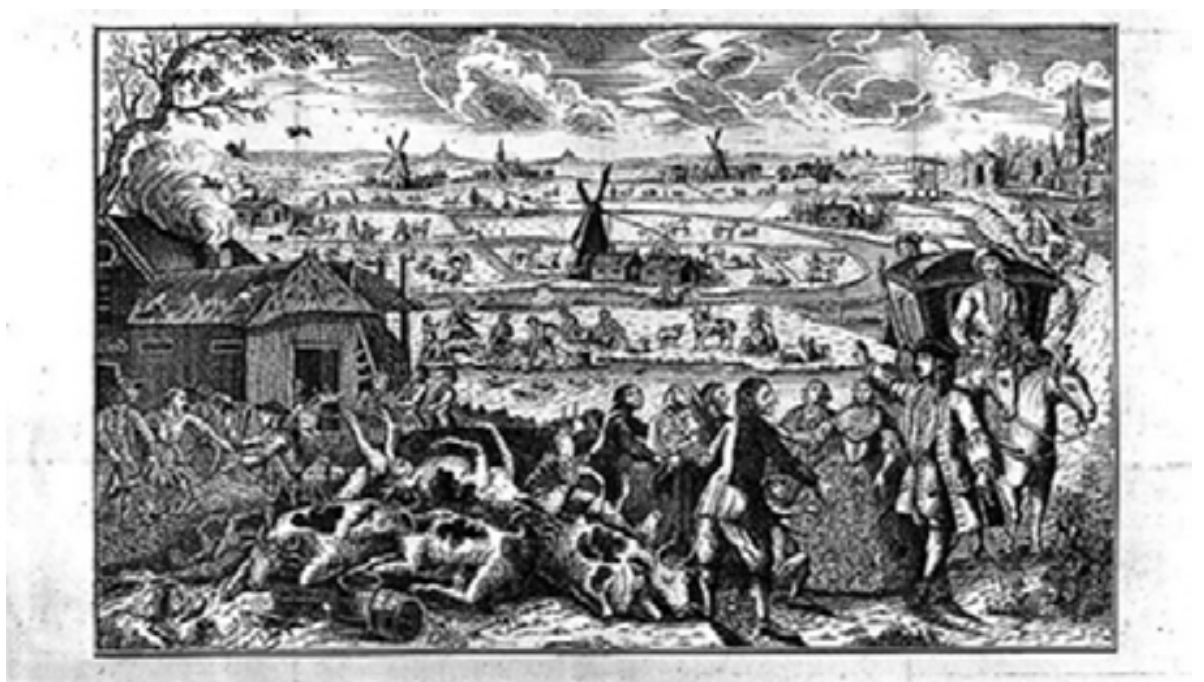

CODS SLAANDE HAND OVER NFDERLAND DOOR DE TEST-SIEKTE ONDER HET RUND VEE.

Figure 2. Gods slaande hand over Nederland door pest-siekte on het rund veen. Jan Smit, Bookprint, 1745

Areas with a high density of cattle and more extensive trading of cattle were more severely affected. Particularly, the current province of Fryslân was among the more severely struck areas. For example, during the outbreak of 1744, approximately 135,000 cattle died out of an estimated total of 160,000 (Faber 1962). It was also noted that outbreaks particularly occurred during winter when cattle were housed in often poorly ventilated barns. Currently we would publish such findings in peer reviewed journals using odds ratios and confidence intervals to show the significance of such risk factors.

During the third wave of cattle plague outbreaks, it was Geert Reinders (1737-1815) who showed that cattle inoculated with virulent virus while protected by maternal immunity would only show limited clinical signs and were lifelong protected against subsequent infections with the virus. These findings were later published in the proceedings of the Royal Society in London and are thought to be an inspiration for Edward Jenner who went on to develop the cowpox inoculation as a preventative for human smallpox infections. It should be noted that the Cattle Plague virus is now the second virus that has been eradicated worldwide, only the second after the successful worldwide eradication of smallpox (Morens et al. 2011). 
It may be argued that these outbreaks of cattle plague not only were the birthplace of veterinary epidemiology and immunology, but also resulted in the development of organized farm animal health programmes in the Netherlands and other European countries. By describing this initial disaster in organized farm animal health programmes in the Netherlands, my aim is to take you along to the current situation where the Netherlands is among the most progressive countries in ensuring health of farm animals.

In the first half of the $19^{\text {th }}$ century, the veterinary college in Utrecht was established, initially focused on horse medicine and surgery but certainly also involved in finding solutions for cattle disease. Another important step forward from the not so effective programmes in the $18^{\text {th }}$ century was the start of the Frisian Health Service for cattle in Leeuwarden in 1919. Not surprisingly this initiative took place in the province of Fryslân where again cattle density was relatively high and the importance of animal agriculture on the socio-economic status of the province was high.

At the end of the $19^{\text {th }}$ century and the beginning of the $20^{\text {th }}$ century, animal diseases were certainly impacting the health status of farm animals and in some cases also the health status of people. Dominant diseases at that point in time included foot and mouth disease, abortions caused by Brucella abortus, tuberculosis caused by mycobacterium bovis and cattle grubs due to hypoderma bovis.

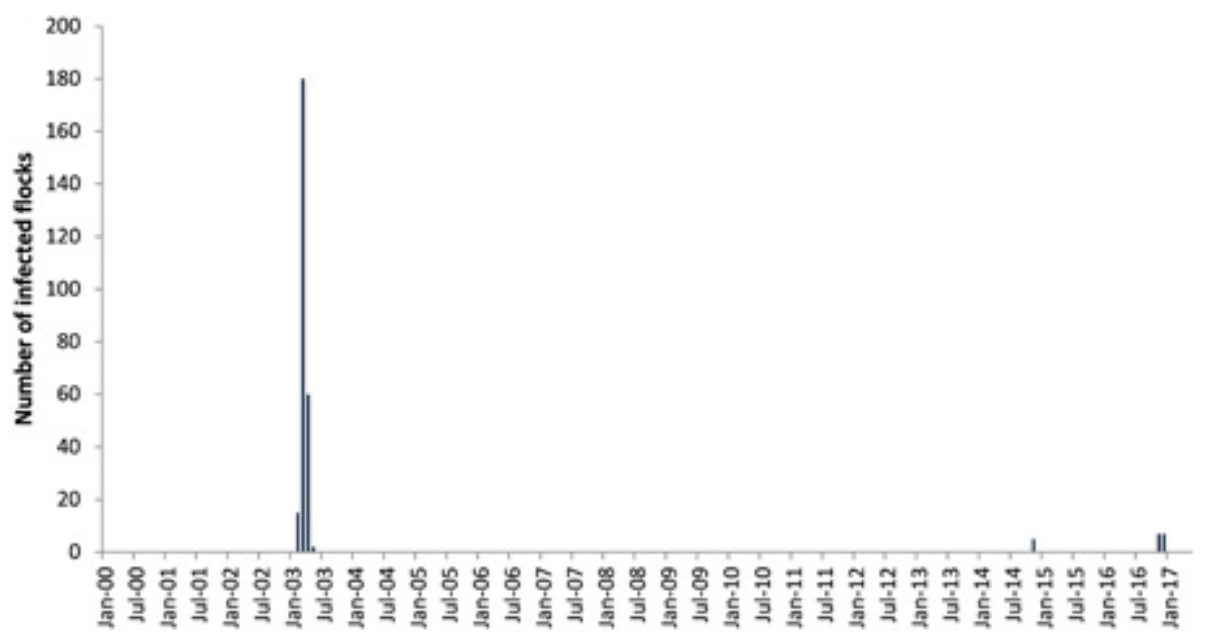

Figure 3. Outbreaks of High Pathogenic Avian Influenza in the Netherlands from 2000 to 2017. 
The Frisian Health Service for Cattle started in 1919, and was an initiative of the Frisian Herdbook (FRS) and the dairy cooperatives in the province. The driver of the initiative and also its first director was Dr. Veenbaas, a veterinarian who was working as a hygiene specialist at the Frisian Herdbook.

The success of the initial Health Service in Fryslân was soon the reason for formation of provincial animal health services across the country. These provincial animal health services were eventually the drivers behind the eradication of a number of important farm animal disease agents from the Netherlands. Examples of this include the eradication of bovine tuberculosis, Brucella abortus, hypoderma bovis, bovine leukosis and the endemic presence of fouth-and-mouth disease from the Netherlands. In the area of poultry health infections such as Salmonella gallinarum, Salmonella pullorum en mycoplasma gallisepticum. Eventually the provincial animal health services merged into a single GD animal health, located in Deventer, the Netherlands. The work of the GD animal health, for almost 100 years now, has been instrumental in enormous progress in farm animal health.

\section{Progress in Farm Animal Health}

Therefore it is now time to move to a more recent history of farm animal health. Around the turn of the $20^{\text {th }}$ to 21 st century, a number of large outbreaks of list A disease in the Netherlands took place. These outbreaks included Classical Swine Fever in pigs in 1997 and 1998 (Stegeman et al. 200o), Foot-and-Mouth disease in cattle in 2001 (Bouma et al. 2003), and Highly Pathogenic Avian Influenza in poultry in 2003 (Stegeman et al. 2004). At approximately the same time, in 1999, a vaccine contamination of an Infectious Bovine Rhinotracheitis (IBR) vaccine with Bovine Virus Diarrhea (BVD) virus resulted in a major distrust of farmers and consumers towards existing animal health programmes that were at that time mainly focused on a reactive approach to the occurrence of disease and disease outbreaks in farm animals (Barkema et al. 2001, Wuijckhuise et al. 2001, deKruif, 2001).

In a collaborative effort between the levy boards and the government a more proactive approach towards animal health was developed in 2002. The base of this collaborative effort was the start of the GD animal health surveillance programmes, where early signs of health issues were pro-actively obtained through the use of 'big' data analysis (Veldhuis et al. 2016), development of a phone consultancy system for farmers and veterinarians and subsidizing the use of pathology across all farm animal species (Bisdorff et al. 2017). This surveillance programme has shown its effectiveness in the last fifteen years. Outbreaks of list A diseases and new or presently unkown diseases were identified early and could be eradicated before massive spreading throughout the country had taken place (Lievaart-Peterson et al. 2015, Peperkamp et 
al. 2015, vanderHoek et al. 2012). Recent examples of Highly Pathogenic Avian Influence are good examples where early detection and outstanding collaboration between all partners involved has resulted in outbreaks with virtually no spread in the population (figure 3).

The objectives of the surveillance programme are first to early identify outbreaks of infectious disease currently not present in the Netherlands, second to identify the development of new or currently unknown disease that may affect animals or animals and people and third to identify trends and developments in animal health across all farm animal species (Santman-Berends et al. 2016). Ultimately, the objective is to continuously improve animal health and contribute to the improvement of public health.

In recent years, the recognition that infectious disease control is a process that knows no species borders has become dominant. Instead of thinking about animal health and public health as two distinct entities, the concept of One Health is now becoming dominant. In the Netherlands, the establishment of the Netherlands Centre for One Health in 2016 is a good example of these recent developments. At Wageningen, global one health is one of the research focuses.

The surveillance programme is not only focused on List A diseases, but is also an important tool in the reduction or even eradication of more endemic infectious diseases in farm animals. In table 1 , the currently active animal health programmes for the main farm animal species are shown. For a number of these infectious diseases, such as Leptospirosis, Aujeszky disease, Classical Swine Fever, Coxiella burnetii and poultry salmonella, Influenza, Mycoplasma spp. and Newcastle disease the programme is to maintain an infection free status (vanNes 2001, Roest et al. 2011). For other disease, such as bovine and pig salmonella, paratuberculosis and other salmonella in poultry, these are required control programmes and for the remainder of the diseases such as udder health, calf health and Neospora caninum it concerns voluntary health programmes.

Looking at the number of diseases in table 1 , it is clear that the ambition among the leaders of the farm animal health community is impressive and has over the years resulted in a farm animal health status in the Netherlands that is among the highest in the developed world. 


\begin{tabular}{|c|c|c|c|c|}
\hline Dairy cattle & Pigs & Poultry & Beef cattle & Small ruminants \\
\hline $\begin{array}{l}\text { - Salmonella } \\
\text { - Paratuberculose } \\
\text { - Leptospirose } \\
\text { - Brucella } \\
\text { - IBR } \\
\text { - BVD } \\
\text { - Udder health } \\
\text { - Calf health } \\
\text { - Neospora } \\
\text { caninum }\end{array}$ & $\begin{array}{l}\text { - Aujeszk } \\
\text { - Classical Swine } \\
\text { Fever } \\
\text { - Porcine } \\
\text { Epidemic } \\
\text { Diarrhea (PED) } \\
\text { - Porcine } \\
\text { Respiratory and } \\
\text { Reproduction } \\
\text { Syndrome } \\
\text { (PRRS) }\end{array}$ & $\begin{array}{l}\text { - almonella pullorum } \\
\text { - Salmonella } \\
\text { gallinarum } \\
\text { - Salmonella spp. } \\
\text { - Avian Influenza } \\
\text { - Mycoplasma } \\
\text { - synoviae } \\
\text { - Mycoplasma } \\
\text { gallisepticum } \\
\text { - NewCastle Disease }\end{array}$ & $\begin{array}{l}\text { - Leptospirose } \\
\text { - } I B R \\
\text { - } B V D \\
\text { - Calf health }\end{array}$ & $\begin{array}{l}\text { - Coxiella burnetii } \\
\text { - Caprine Arthritis } \\
\text { Encephalitis } \\
\text { - Maedi-visna } \\
\text { - Brucella } \\
\text { - Caseous lymphadenitis }\end{array}$ \\
\hline
\end{tabular}

Table 1. Required and voluntary animal health programs currently being in place across the Netherlands.

Next, I would like to impress you with some examples of remarkable progress in farm animal health.

The first example of progress in animal health and an associated decrease in human infections is shown in Figure 4 with regard to zoonotic Salmonella infections in poultry flocks. The steady decrease in the percent of poultry flocks infected with Salmonella is the leading force in the reduction of the number of human Salmonella cases. It should be noted that since 2012 no national flock infection data has been reported. It is of some concern that human cases therefore currently serve as a sentinel for Salmonella infection dynamics in the poultry population. (Uiterwijk et al. 2016).

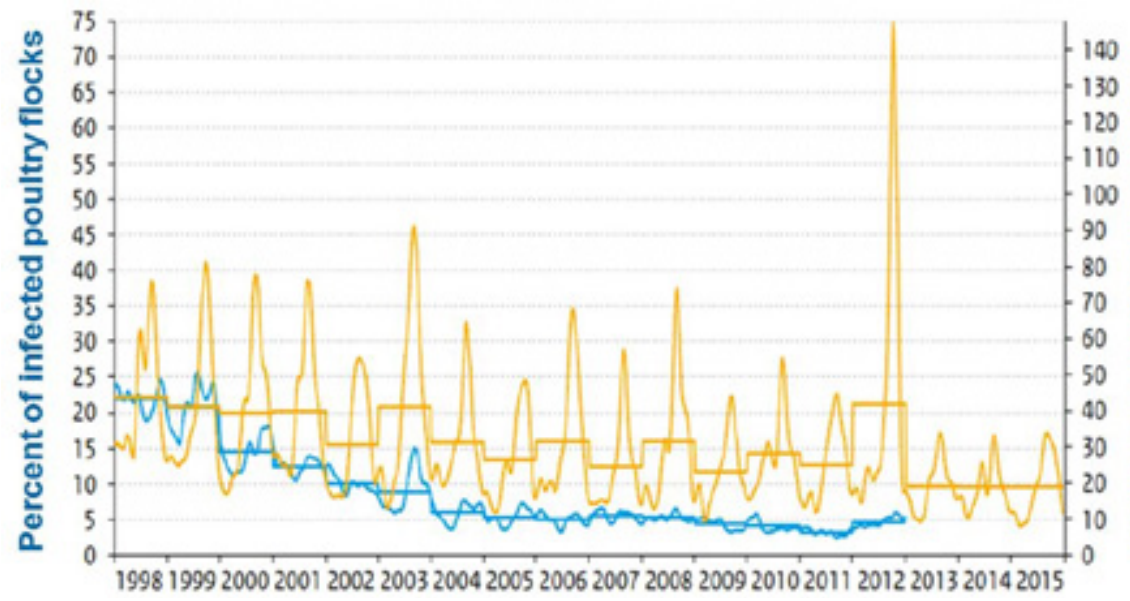

Figure 4. Number of Salmonella cases in humans reported to the National Institute of Public Health and the percent of poultry flocks known to be Salmonella infected. From Uiterwijk et al. 2016. 


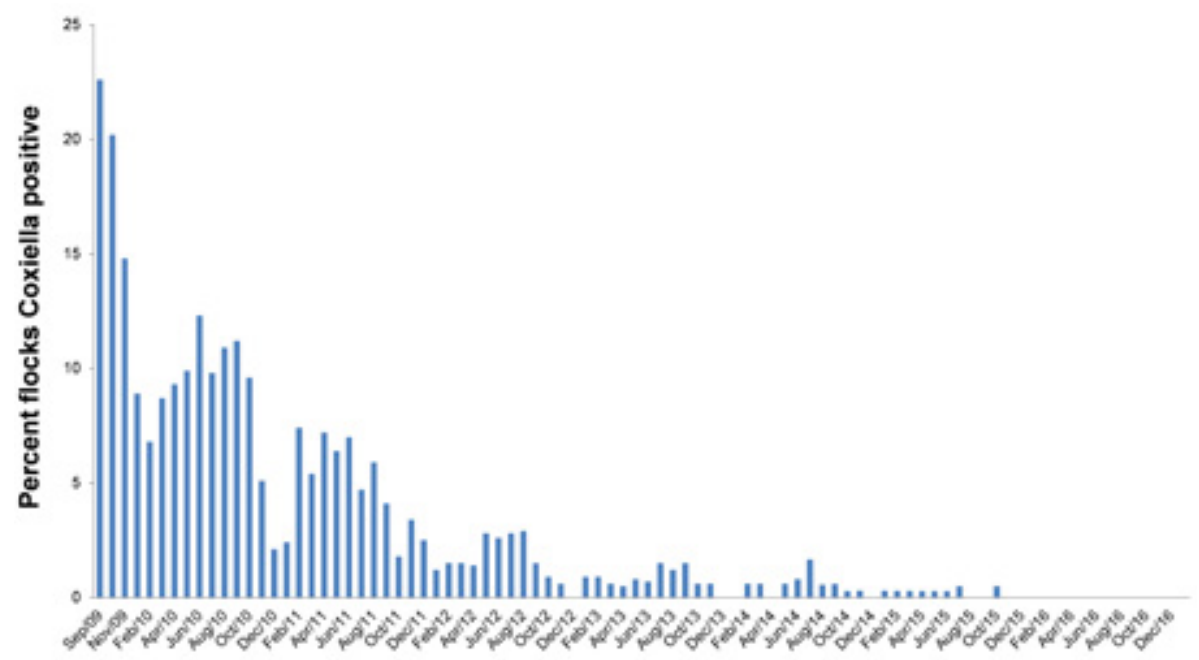

Figure 5. Percent of goat flocks positive in bulk milk for Coxiella burnetii. Data from GD Animal Health.

The second example is Q-fever or Coxiella burnetii in goat herds. From 2007 to 2009, a major outbreak of Coxiella burnetii occurred among Dutch goat farms. It turned out that the goat farms were also the major source of a large outbreak of Q-fever in the human population that was living in the area where goat farms were located (van der Hoek et al. 2012). This outbreak of a zoonotic infectious disease has resulted in a major control programme of Coxiella burnetii infections in goat farms (vanderHoek et al. 2012). Affected herds were required to cull pregnant animals, susceptible animals were vaccinated and animals that were potentially infected were not to be used for breeding during the remainder of their life on the farm. Mandatory surveillance of Coxiella burnetii infection status was also part of the control programme (Roest et al. 2011). This control programme that started in December 2009 has eventually resulted in the virtual absence of Coxiella burnetii positive bulk tanks starting in December 2015 (Figure 5).

The third example is with the Newcastle Disease vaccine titer program. Newcastle disease in poultry is a contagious infectious disease caused by a paramyxovirus in poultry that is controlled in the Netherlands using required vaccination of poultry flocks (Senne et al. 2004). A major concern in early 2000 was the inadequate use of vaccines in poultry flock. Up to $25 \%$ of flocks did not show the presence of sufficient antibody titers. Since the start of a vaccination follow-up programme that started in 2007, the percent of flocks that does not meet the vaccination standards has been reduced from approximately $25 \%$ to currently approximately $3-4 \%$ (Figure 6 ). Such high and effective vaccine coverage is essential for a country to remain free of Newcastle Disease. 


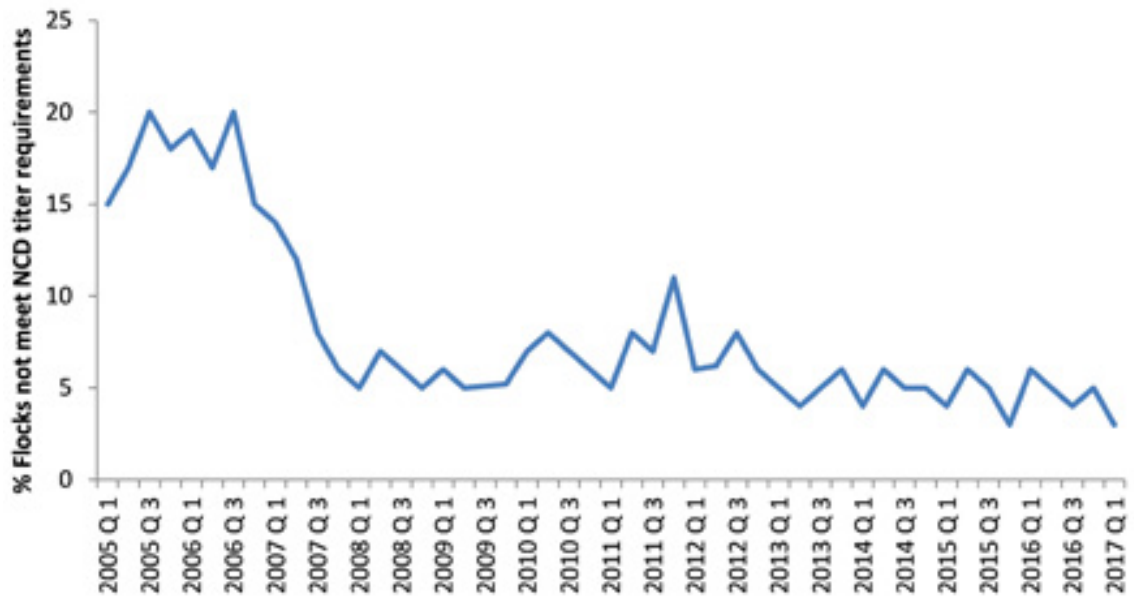

Figure 6. Percent of poultry flocks that do not meet the requirements for vaccine titers against Newcastle Disease. Data from GD animal health.

The fourth and final example is the control programme for Infectious Bovine Rhinotracheitis or IBR and Bovine Viral Diarrhea Virus or BVDV. As mentioned earlier, an attempt to eradicate IBR from the Netherlands around the turn of the century was aborted due to the presence of contamination with Bovine Viral Diarrhea virus of the vaccine (see for example De Kruif 2001, Barkema et al. 2001). It was not possible to continue a required vaccination programme of cattle in the face of possible vaccine contamination. In recent years a new programme focusing on the reduction of the number of farms infected with either IBR or BVD has been started. The programme has currently started on a voluntary basis, but it is expected that in the upcoming years some form of a national control programme will be started. However, already the pro-active response of many dairy farmers has been to participate in voluntary surveillance and infection free certification programmes. The results of these voluntary programmes has been an impressive increase in the number of certified BVD free herds (GD animal health certification programme) and a general decrease in the estimated prevalence of herds with a known active BVD infection.

A relatively new component of the national farm animal health surveillance programme is the national surveillance of endemic diseases in pig herds, a form of syndrome surveillance. Across all pig farms in the Netherlands, clinical disease symptoms are entered into a national database by the practicing veterinarians and reported back to all veterinarians and shortly also to the farmers. The example in figure 7 is the recent reporting of herds with at least one animal with clinical neurological disorders. As can be seen from this density map, there is currently no 


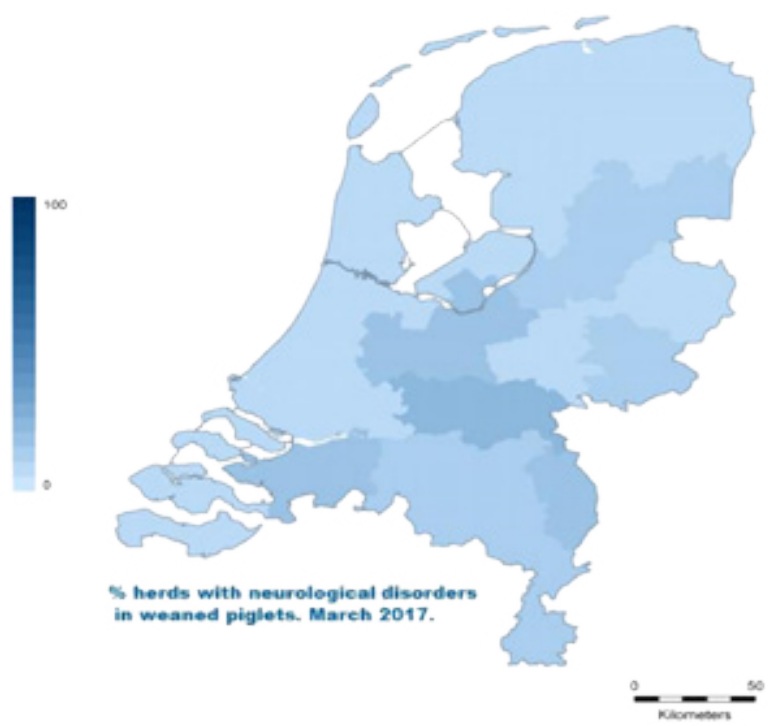

Figure 7. National overview of prevalence of neurological disorders in weaned piglets. Data from GD animal health.

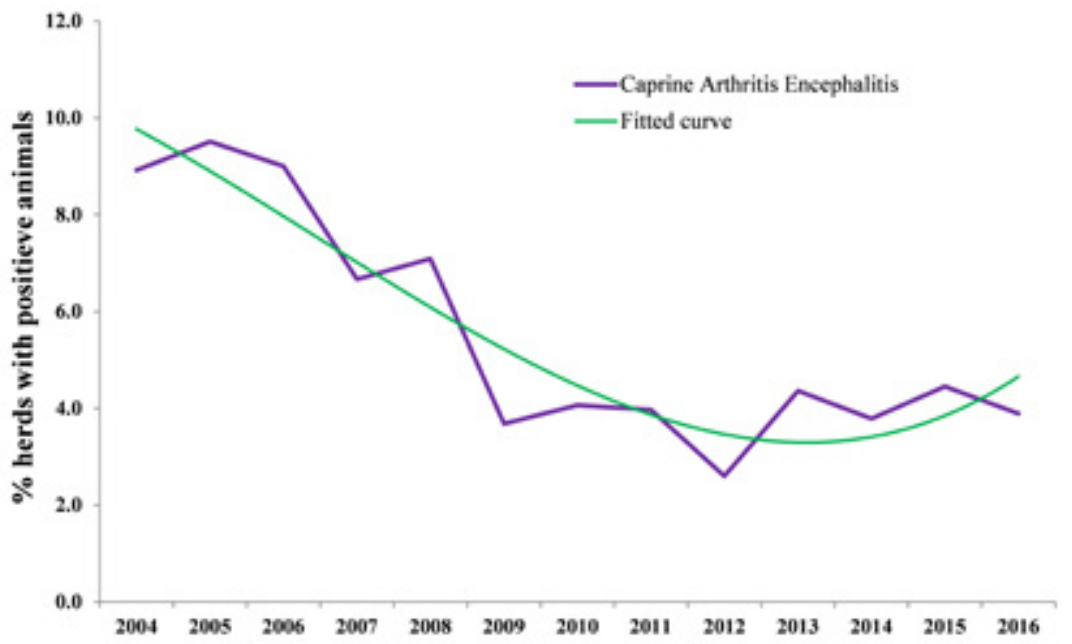

Figure 8. Percent of goat herds with known caprine arthritis and encephalitis (CAE) positive animals. Data from GD animal health 
reason for specific concerns, but there are some reasons to keep an eye on the development in the south of the country. Infections that may be associated with clinical neurological disease would include Streptococcus suis and Escherichia coli. This amazing initiative allows the continuous surveillance of clinical disease, so called syndrome surveillance, on a continuous and virtual live basis throughout the country. This initiative is certainly something that could be used in other populations in the Netherlands and abroad.

These examples all indicate that Farm Animal Health in many cases is making enormous progress. In any case the health data of farm animals are well known and this surveillance allows for a transparent production of food.

\section{Problems in Farm Animal Health}

However, not all programmes are as successful as shown in the above mentioned cases. There are other diseases in farm animals that have proven to be more difficult to control. With regard to Caprine Arthritis and Encephalitis (CAE), control programmes in other countries have shown to be effective in virtually eliminating the virus from the small ruminant populations (Thomann et al. 2017). Data from the Netherlands show an initial reduction in the percent of herds that are positive for both Maedi-Visna and CAE infections, but at the same time in more recent years an increase in the number of herds that are positive with regard to CAE infections (Figure 8). The increase in the number of CAE affected herds since 2012 is of increasing concern and highlights the importance of continuous efforts in control programmes to maintain a low prevalence.

Control of Salmonella serotype B-D infections in dairy herds initially showed a sharp reduction in the number of herds with positive bulk milk antibody titers. However in recent years this progress has stopped, and the prevalence of herds that shows a positive bulk milk antibody test remains at approximately $10 \%$ with a distinct seasonality. Antibody titers have always been highest in the third and last bulk milk testing cycle in each calendar year. Although progress has been slow in recent years, this finding of persistence of Salmonella in approximately $10 \%$ of herds is very similar to what is observed in a National control program in Denmark (Nielsen et al. 2010).

Similarly, control of paratuberculosis in dairy herds has shown progress since the start of the control programme in 2008, but progress has been relatively small and the approximate prevalence of Mycobacterium avium subspecies paratuberculosis (MAP) positive cows has shown a reduction from approximately $1.5 \%$ of cows in 2008 to approximately $1 \%$ of cows in the most recent surveillance results (Figure 9). Several modeling studies have shown recently that control programmes that are aimed at eliminating high shedders of paratuberculosis are biologically and economically 


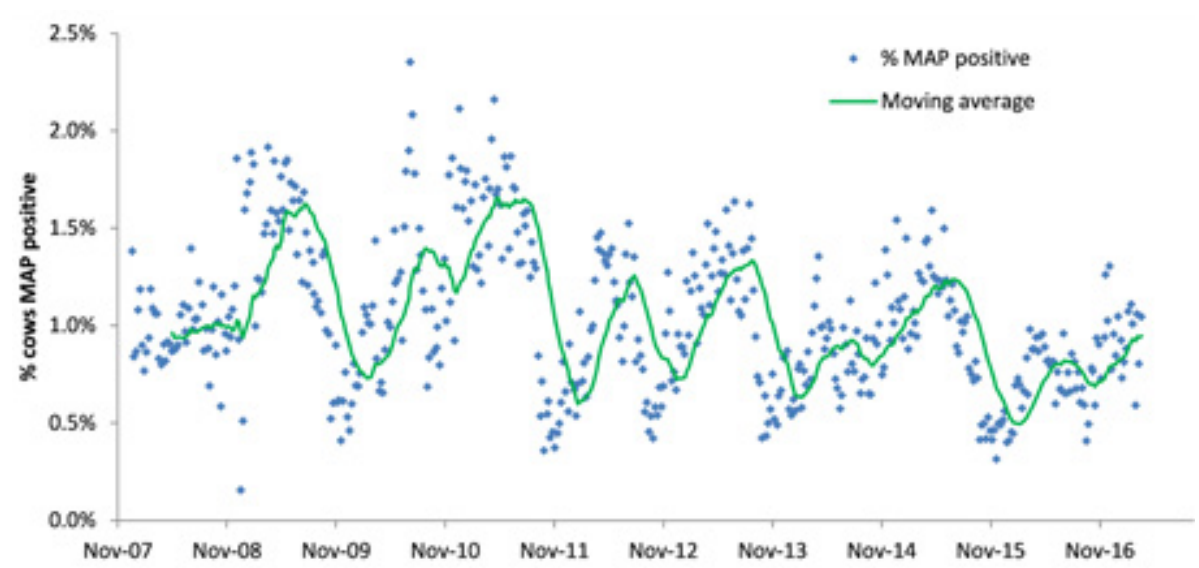

Figure 9. Percent of dairy cows positive in milk ELISA for mycobacterium avium subsp paratuberculosis (MAP) in the Netherlands. Data from GD animal health.

effective, whereas complete elimination of paratuberculosis from endemically infected herds and areas has repeatedly shown to be not a cost efficient approach (Kirkeby et al. 2016, Al-Mamun et al. 2016). In any case, the required control programme aimed at eliminating high shedders certainly means that the number of shedders on farms in the Netherlands will be among the lowest in the world. I will discuss the complexity of endemic MAP infections later.

As a final example of difficulties in controlling an endemic disease, data on bulk milk somatic cell counts over the last decade are presented. Bulk milk somatic cell counts (SCC) have shown a steady progress in the last decade. In most recent months, a slight increase in bulk milk somatic cell count was reported. However, there is quite a different trend in terms of the number of herds with a high percentage of cows with an increased individual somatic cell count immediately after calving (Figure 10). These mastitis data are of particular interest as there has been a substantial decrease in the use of antibiotic treatments in cows over the last years. Antibiotic use in dairy cows has decreased by approximately $60 \%$ since 2009 , this decrease in antibiotic use is mainly due to the elimination of blanket dry cow treatment. With the reduction in the use of dry cow antibiotic treatment, it may be expected that new infections across the dry period will increase (Scherpenzeel et al. 2014). This increase in new infections across the dry period is likely what is observed when monitoring the number of herds with a high percentage of cows with increased SCC post partum.

Summarizing the findings on these endemic infectious diseases would indicate that although farm animal health has shown substantial progress in recent years, not all 


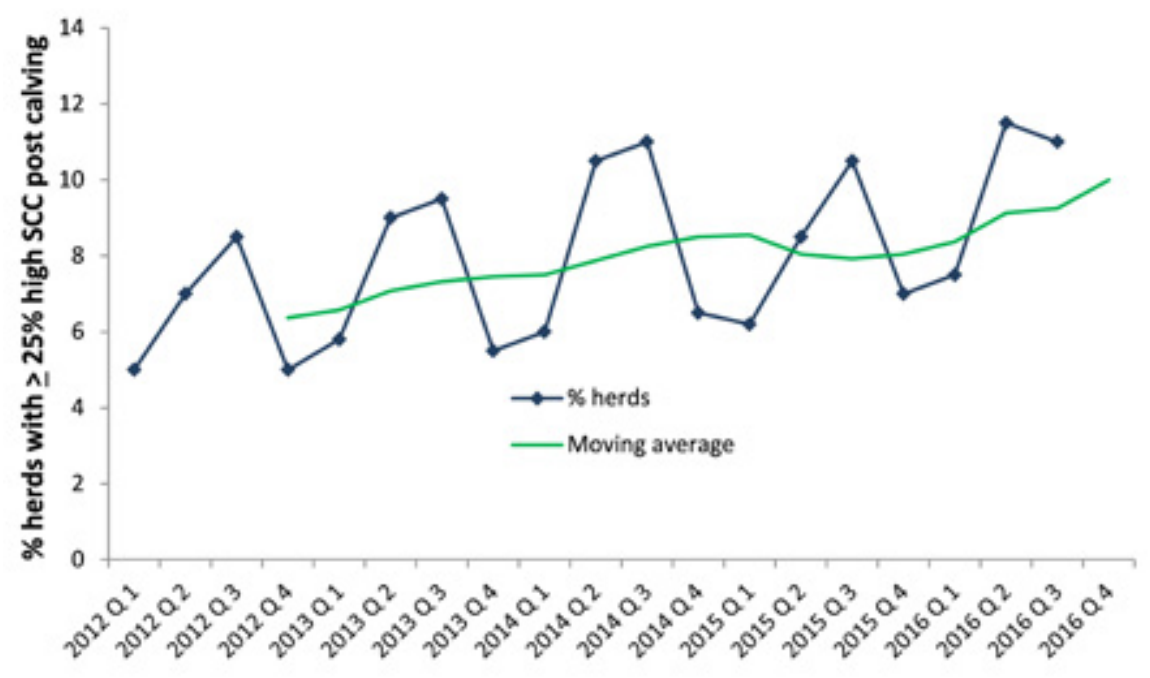

Figure 10. Percent of herds with at least $25 \%$ of cows with high individual milk SCC immediately post calving. Data from GD animal health.

infectious diseases show the same decreasing trend. A number of endemic infectious diseases remain relatively stable in the animal population in the Netherlands or even show an increase in occurrence. In the final part of this public lecture I will discuss the perspectives to perform focused research on these endemic infectious disease in farm animals.

\section{Farm animal health Perspectives}

First of all, the biodiversity and genetic creativity in both hosts and pathogens will inevitably result in a continuous exposure of animals to new infectious challenges. Infectious diseases in farm animals will continuously evolve and therefore there will always be a challenge to animal health. Continuous intense surveillance is therefore essential to remain pro-active in terms of infection vigilance.

For many reasons, control of infectious disease will require more effort with increasing population size. These principles have first been shown for infectious diseases such as measles in smaller versus larger cities or smaller versus larger islands. As indicated earlier, this principle was already known in the case of Cattle Plague in the late $18^{\text {th }}$ century. Herds across all farm animal species have been growing for many years and likely will continue to grow in the years to come. So there is economy of scale when the herd size increases with regard to housing, labour and equipment, but the very opposite is true for control of infectious diseases. With increasing herd size a larger effort per animal is required to maintain the same health status (Figure 11). Larger 
herds are not per se more likely to become infected, but once infectious diseases are present, larger herds will need to spend more effort for a longer period of time to have the same impact on infection control compared to smaller farms (Lu et al. 2010).

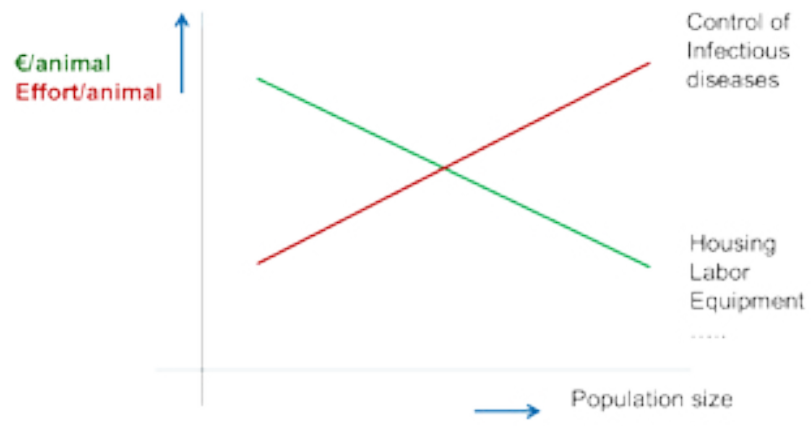

Figure 11. Economy of scale applies to general costs such as housing, labor and equipment, but does not apply to the effort needed to control infectious diseases.

An important method that we have been using in better understanding the persistence of infections in herds is through modelling studies (Mitchell et al. 2015). These studies are particularly useful to evaluate hypotheses that are not easily tested in field situations or in challenge studies. Mathematical models have therefore been particularly relevant in increasing our understanding of infectious diseases such as paratuberculosis in dairy cattle.

\section{Paratuberculosis: the riddle of endemic low prevalence}

In the case of paratuberculosis we have shown, with the help of modeling studies fed by longitudinal field data, that the riddle of a low prevalence endemic disease could be explained. The riddle was the presence of an infection with a very low prevalence that was able to remain endemic in the vast majority of herds. How come an infection remains endemic in a herd when only 1 or $2 \%$ of animals are infected?

The riddle was solved by showing using modeling studies that shedders alone were not able to maintain the infection and that the importance of latent infected animals was much higher than previously expected. In reality it turned out that approximately $25 \%$ of animals in a herd were infected, the vast majority of these are not generally shedding but these animals still contribute to the infection dynamics.

While working on these models and at the same time collecting extensive field data, it was also possible to show that adult animals may still be infected later in life, that 
vertical infection remains a path of infection but of relatively little importance and that infected animals can be divided into progressors and non-progressors. Progressors are cows that show a continuous increase throughout their life in the number of MAP bacteria that are shed. These progressing animals will eventually become heavy shedders and in some cases super-shedders. Non-progressors are infected animals that continue to shed very low number or are shedding intermittently. During the course of our longitudinal studies these animals never progressed to a higher level of shedding. These findings also pose new questions: are there host or bacterial genetics playing a role in the infection pattern?, can we predict the outcome of infection early in life?, and what management factors may predict becoming a progressor or nonprogressor (Schukken et al. 2015)?

Even though we now understand endemic stability of paratuberculosis, we still are not able to interfere and eliminate the infection from farms. We are currently also assuming that all infections in a dairy herd are clonal, while sequence data of the strains show that there is substantial difference between isolates.

Current research is now focused on modeling the value of controlprogrammes on the possible shedding of bacteria in milk, this is really a risk analysis approach. Our initial data would indicate that given a proper control programme, shedding in milk is absent or very low (figure 12). Such studies would further validate the approach that has been used now in the Netherlands to virtually eliminate the presence of mycobacterium paratuberculosis in milk (Beaver et al. unpublished data, 2017). Pasteurization of the milk before consumption will do the rest.

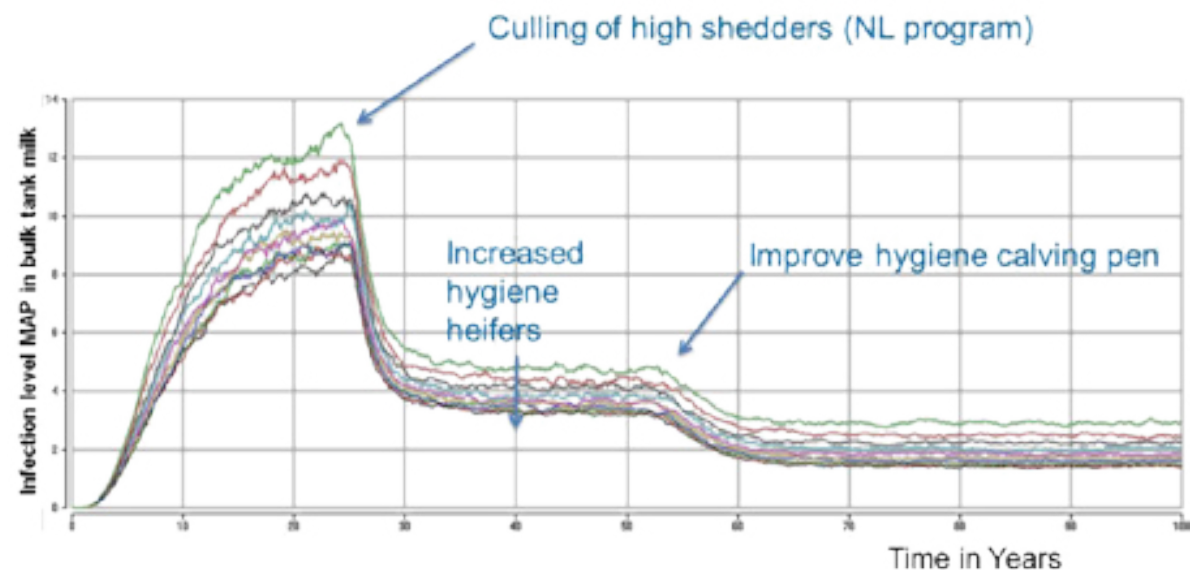

Figure 12. Number of colony forming units in bulk milk from a simulation study where all heavy shedders are actively culled. From Beaver et al. unpublished data. 


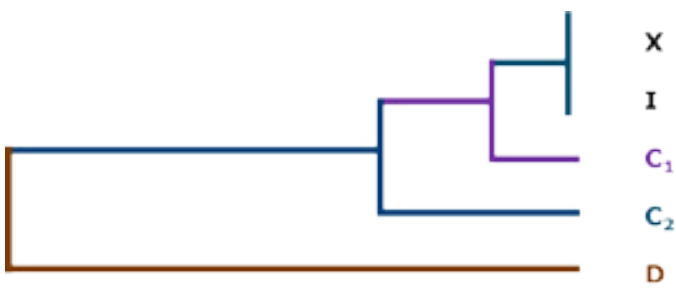

Figure 13. Phylogenetic tree of bacterial isolates

representing their genetic distance. $X$ represents the index

case, $I$ is identical to the index case, $C_{1}$ and $C_{2}$ are 1 and 2

generations away from the index case and $D$ is a

non-related isolate. From Grad and Lipsitch, 2014.

Another area of current research is the use of whole genome sequencing of pathogens to improve our understanding of the specific routes of infections in herds. The genome data are useful for a number of reasons. Comparing sequences of isolates collected over the course of an infection in the same animal will tell us about the rate of evolution of pathogens, the so-called clock speed. Then, probably most exciting is the comparison of multiple isolates obtained throughout an outbreak and use the data to infer the rates and routes of transmission. Such analyses may provide information on the underlying infection network and suggest methods to interfere with key infection routes. For example, when there are five isolates that are identified here as $\mathrm{X}, \mathrm{I}, \mathrm{C}_{1}, \mathrm{C}_{2}$ and D (Figure 13). in this example $\mathrm{X}$ is the initial isolate from the index case, $\mathrm{I}$ is identical to the index case. After the first transmission to another animal in the same herd, $C_{1}$ represents the first contact infection and $C_{2}$ reflects the second generation contact infection, infected from the animal carrying $C_{1}$. The isolates $C_{1^{\prime}}$ and $C_{2}$ are progressively further away from the original isolate both in genetic distance and epidemiological distance, whereas isolate $\mathrm{D}$ is clearly from a distinct infection process (Grad and Lipsitch 2014). Such genomic data combined with precise epidemiological data allows us to precisely trace infection processes in populations (Ypma et al. 2012). Finally, comparing sequence data may also provide insight on mutation rate and evidence for bacterial adaptation due to selection pressure from interventions such as bacterial treatments or vaccinations.

We recently sequenced 365 mycobacterium avium subspecies paratuberculosis (MAP) isolates that were collected during a ten year longitudinal study on three dairy farms, the regional dairy quality management alliance (RDQMA) study (Schukken et al. 2015). Whole genome sequencing as shown allows some further understanding of infection dynamics with and between herds in this large 
longitudinal study on three dairy farms (Figure 14). The sequence results of the isolates show the large core genome of MAP and the relatively small variable genome. The results also indicate that the isolates from farm II en III are relatively close and a clonal outbreak appear likely. These data will be analyzed in more detail in our future research to connect precise longitudinal epidemiological data with whole genome sequencing.

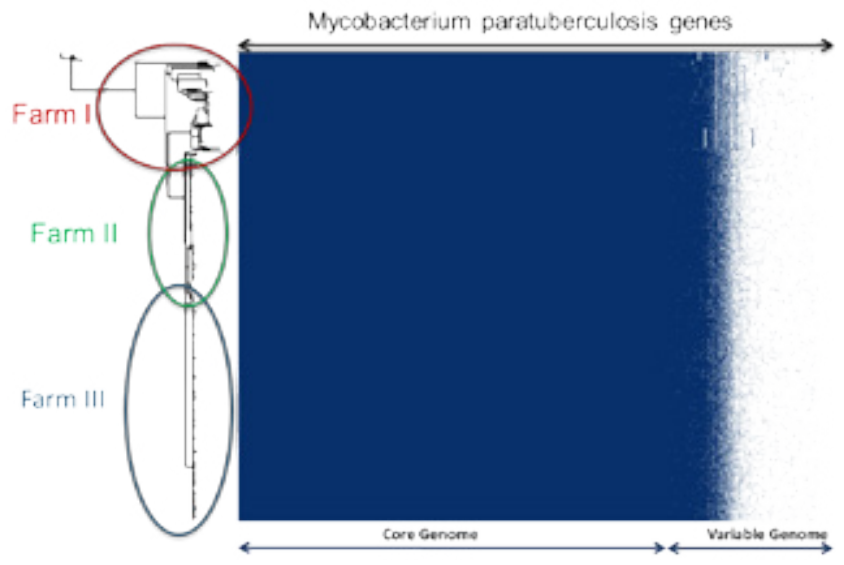

Figure 14. Whole genome sequencing of 365 isolates from three RDQMA herds. Genes that are present in all isolates are identified as the core genome, genes present in a selection of isolates represent the variable genome. Isolates are clustered by phylogeny and by herd. From Stanhope and Nigsch, manuscript in preparation.

Using these sequence data we can answer questions such as: is there an outbreak from a single pathogen or are there multiple parallel infection processes going through the farm, where did the pathogen initially come from, is there evidence for farm-to-farm transmission, how and how fast is the pathogen being transmitted from one animal to the next, how is the pathogen spreading through the population of farms and then what genes are associated with the virulence of the pathogen and is this pathogenicity evolving over time? Many of the answers to these questions will allow us to further develop and fine tune control programmes for paratuberculosis on dairy and goat farms.

\section{Mastitis: high risk of infection in late gestation}

Another important application of the interaction of molecular genetics and epidemiology is in the field of bovine mastitis. As shown in the population data earlier, mastitis remains an issue in our dairy herds. Having lactating animals around will 
inevitably result in some frequency of intramammary infections. However, reducing the number and severity of infections remains an important focus for improvement. As shown in the data from the Netherlands, there is currently a specific issue with infections that either persist or develop across the dry period. The dry period in dairy cows is a specific dynamic period in the life of the cow. On the one hand it provides a period of restoration of the mammary epithelium and time of relative low risk of infection due to several innate and adaptive immune systems. On the other hand it turns out to be a high risk period as management of dry cows is often somewhat neglected and the cow in late gestation is reprogramming its immune response toward a Th-2 dominated response or an immune response that is more permissive of infections without mounting a substantial immune response to remove potential invading micro-organisms (Quesnell et al. 2012). Several recent studies from our research team have been focused on the immune response during late gestation showing that the both Natural Killer cells and Dendritic Cells play an important role in directing the immune response in late gestation (Pomeroy et al. 2015, 2016, Sipka et al. 2016).

Still the dry period remains a high risk period. This is particularly an issue of increasing importance since the reduction in the use of antibiotics where the vast majority of antimicrobial use reduction is due to a much more selective use of dry cow antibiotics. An important focus of research will therefore be on a better understanding of the risk of new infections across the dry period. Several studies have shown that approximately $20 \%$ of quarters will experience a new intramammary infection across the dry period (Green et al. 2005). This also means that $80 \%$ of animals will not experience this. The characteristics of these $80 \%$ of quarters are therefore of great interest. Risk factors for new infections across the dry period have been studied and include milk production at the time of dry off, high somatic cell count before dry-off, teat end lesions and closure of the teat canal. These risk factors are of some value, but it is not always easy to intervene with these risk factors.

More recently, we have been doing research on the importance of the mammary microbiome, the native bacterial populations that reside in the healthy mammary gland. In itself a paradigm shift that the healthy mammary gland contains bacteria, but even more interesting is the hypothesis that the constituents of the healthy microbiome may be protective against superinfection with pathogenic bacteria. Studying the relationship between the mammary microbiome and the somatic cell count of the milk resulted in a negative correlation with the amount of bacteria of the paenibacillus genus. Indicating that more of the paenibacillus bacteria resulted in a healthier gland (Oikonomou et al. 2014). The healthy microbiome of the mammary gland shows an enormous amount of diversity while mastitis affected glands show 
an overgrowth with pathogenic bacteria and a substantial loss of bacterial diversity. In a recent $E$. coli challenge study, we evaluated the microbiome before challenge as a predictor of the outcome of challenge. Microbial diversity before challenge and the bacterial species present in the mammary gland before challenge were among the factors that predicted the outcome of challenge. Similarly, effective treatment of infected glands not only reduced the number of $E$. coli bacteria, but also resulted in a faster return to high diversity of microbiota of the mammary gland (Ganda et al. 2017).

Further research in the functional capacity of the mammary microbiome will help us further explore the value of a diverse microbiome in prevention of infection and disease in the mammary gland. A valuable concept in this regard is the concept of resilience. The resilience of a system determines its response and adaptation to sudden changes (Scheffer et al. 2001), in the case of the mammary gland such changes would be the introduction of pathogenic bacteria (Figure 15). Studying resilience of eco-systems is not only of scientific interest, of interest to the dairy industry and of interest to the cow, it is also one of the five promising research areas in the Wageningen University and Research strategic plan 2015-2018 (http://www.wur.nl/en/ About-Wageningen/Strategic-Plan.htm).

Placing our research on farm animal health in the forefront of the WUR strategic academic investment also allows me to highlight the importance of one of the main drivers of success in agricultural innovation. Throughout the years, the golden triangle is one of the great attributes of progress in agricultural and life sciences research in the Netherlands. The golden triangle describes the partnering of academics, government and the agricultural industry.

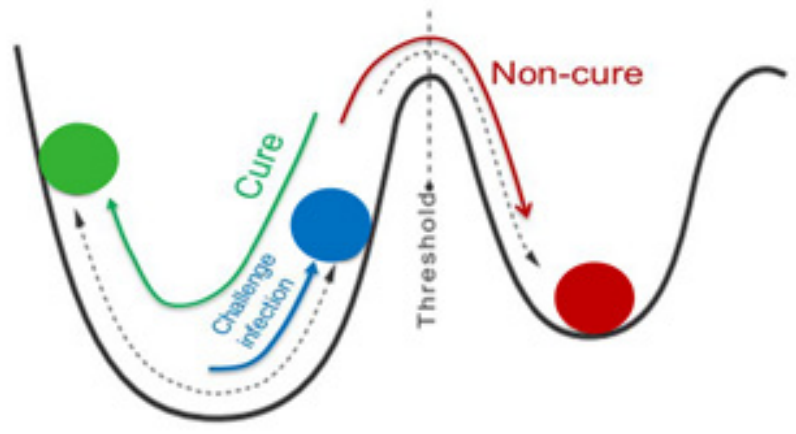

Figure 14. Whole genome sequencing of 365 isolates from three RDQMA herds. Genes that are present in all isolates are identified as the core genome, genes present in a selection of isolates represent the variable genome. Isolates are clustered by phylogeny and by herd. From Stanhope and Nigsch, manuscript in preparation. 
I have described farm animal health in the Netherlands and concluded that the current status of health is among the very best in Europe and, likely, the world. To reach this status, it required a very practical application of the golden triangle to make this happen: a strong academic research programme at both Wageningen and Utrecht University, a government who has been very supportive in funding research and also in facilitating animal health programmes and an agricultural business that has made long term commitments to animal health and wellbeing.

There are currently challenges to maintain the strength of this unique collaboration. However, I trust that in the near future it will be possible to strengthen the triangle again by allowing the agricultural organization to raise funds for animal health research and surveillance. It would be of great societal importance to continue to rely on the historical and unique strength of the golden triangle as a pro-active measure rather than waiting for the next outbreak of a known or currently unknown disease to force a re-thinking of the current policies.

\section{Conclusions}

Coming to the end of my inaugural lecture, I would like to summarize the key messages that I am sharing with you today.

Animal health in the Netherlands is among the very best in Europe and the world. The transparency of the animal industries with regard to the health of the animals is unsurpassed.

The Netherlands has a unique and well developed animal health surveillance system in place. Animal health has been an outstanding example of the success of the concept of the golden triangle. I discussed the challenges to maintain the strength of this unique golden triangle. Today we started out with a description of the Cattle Plague, and it is my sincere hope that it will not take another outbreak like the cattle plague to make us realize how valuable the golden triangle is.

The abundance and genetic creativity of life around us means that there will never be a dull moment. Infectious diseases in farm animals will continuously evolve and therefore will always pose a challenge to animal health. Infectious agents will always be present in farm animals and are likely to cause continuous concern to animals, animal owners and in selection of cases to public health as well.

For that reason, farm animal health is never 'finished' or 'completed'. It remains necessary to remain vigilant and continue surveillance for appearance of existing or new infectious diseases and to maintain a precise understanding of disease dynamics 
in animal and human populations. With my research team working on infection dynamics of endemic disease, I hope to contribute to this.

\section{Thanks}

At the end of this inaugural lecture, I would like to take this wonderful opportunity provided in this public lecture to thank those that are dear to me. First of course, my appreciation to you all for coming. It is a great pleasure for me to see you all here from the podium.

I also would like to thank Aalt Dijkhuizen and Martin Scholten for making this appointment as special professor possible, I would like to thank the members of the appointment advisory committee for their support and their positive advice. Of course the Chair of my chair group, Prof. Mart de Jong and my colleagues in this chair group Klaas Frankena and Lisette Graat. Special thanks and my very best wishes to Ada Wiggerman, our superb office support person.

It is a pleasure to combine my work as a scientist at Wageningen University and Research with my position at GD Animal Health. I would like to thank my colleagues at GD for creating a wonderful and exciting work environment; there is never a dull moment. Many thanks also to the Board of Directors GD for your trust in me.

I very much appreciate the close collaboration with my colleagues throughout the years while working at Utrecht University, Cornell University, University of Warwick and now Wageningen and again Utrecht. Some of you are here with us today. A special thanks to my promotor and friend, Professor Arie Brand, we used to call him professor Fire, I think that says it all. Of course the great collaborations with Mirjam, Tine, Jos, Ruth, Herman, Theo and many, many others have been so much more than just collegial collaboration. One of the great pleasures of working at a University is to work with undergraduate, masters and PhD students and postdoctoral scientists. Without your insights, enthusiasm and fun, we would have never made such progress in our work on farm animal health.

A lot of thanks also to our friends and family who are able to join us here, you visited us while we lived in the US and UK and you were here again for us when we came back to the Netherlands. My four little brothers and their families, it is such a great pleasure that you are all here. Of course, my parents-in-law and 'us mem' always there to pull us together and be the real centre of our large family.

It is an indescribable pleasure to have my own family here today with me. Our children: Aukje, Wytse, Klaske en Jelle, and of course now also Wouter and little Eva. 
While travelling the world you have always formed the very special place to go back to. I am so proud to be your father and grandfather. To be together again in the Netherlands is such a special treat. Of course, throughout these years our family was held together by my dear wife Hetty. As you all know by now, I have apparently succeeded in impressing Hetty enough while showing my interest in her historical research. We have formed a team for over thirty years now. Hetty, you have impressed me so much by being the anchor of my life and the centre of our family. Thank you, I love you.

'Ik heb gezegd' 


\section{References}

Al-Mamun, M.A., Smith, R.L., Schukken, Y.H., Gröhn, Y.T. 2016. Modeling of Mycobacterium avium subsp. paratuberculosis dynamics in a dairy herd: An individual based approach. J Theor Biol. 408:105-117.

Barkema, H.W., Bartels, C.J., van Wuijckhuise, L., Hesselink, J.W., Holzhauer, M., Weber, M.F., Franken, P., Kock, P.A., Bruschke, C.J., Zimmer, G.M. 2001. Outbreak of bovine virus diarrhea on Dutch dairy farms induced by a bovine herpesvirus 1 marker vaccine contaminated with bovine virus diarrhea virus type 2. Tijdschr Diergeneeskd. 126:158-165.

Bisdorff, B., Schauer, B., Taylor, N., Rodríguez-Prieto, V., Comin, A., Brouwer, A., Dórea, F., Drewe, J., Hoinville, L., Lindberg, A., Martinez Avilés, M., MartínezLópez, B., Peyre, M., Pinto Ferreira, J., Rushton, J., Van Schaik, G., Stärk, K.D., Staubach, C., Vicente-Rubiano, M., Witteveen, G., Pfeiffer, D., Häsler, B. 2017. Active animal health surveillance in European Union Member States: gaps and opportunities. Epidemiol Infect. 145:802-817.

Bouma, A., Elbers, A.R., Dekker, A., de Koeijer, A., Bartels, C., Vellema, P., van der Wal, P., van Rooij, E.M., Pluimers, F.H., de Jong, M.C. 2003. The foot-and-mouth disease epidemic in The Netherlands in 2001. Prev Vet Med 57:155-166.

Faber, J.A., Cattle plague in the Netherlands during the eighteenth century. 1962. Meded. Landbouwhogeschool, Wageningen 62, 1-7.

Ganda, E.K., Gaeta, N., Sipka, A., Pomeroy, B., Oikonomou, G., Schukken, Y.H., Bicalho, R.C. 2017. Normal milk microbiome is reestablished following experimental infection with Escherichia coli independent of intramammary antibiotic treatment with a third-generation cephalosporin in bovines.

Microbiome. 5:74-85.

Grad, Y.H. and Lipsitch, M. 2014. Epidemiologic data and pathogen genome sequences: a powerful synergy for public health. Genome Biology 415:538-547.

Green, M.J., Green, L.E., Bradley, A.J., Burton, P.R., Schukken, Y.H., Medley, G.F.. 2005. Prevalence and associations between bacterial isolates from dry mammary glands of dairy cows. Vet Rec. 156:71-77.

van der Hoek, W., Schneeberger, P.M., Oomen, T., Wegdam-Blans, M.C., Dijkstra, F., Notermans, D.W., Bijlmer, H.A., Groeneveld, K., Wijkmans, C.J., Rietveld, A., Kampschreur, L.M., van Duynhoven, Y. 2012. Shifting priorities in the aftermath of a $Q$ fever epidemic in 2007 to 2009 in The Netherlands: from acute to chronic infection. Euro Surveill. 17:20059.

Kirkeby, C., Græsbøll, K., Nielsen, S.S., Christiansen, L.E., Toft, N., Rattenborg, E., Halasa, T. 2016. Simulating the Epidemiological and Economic Impact of Paratuberculosis Control Actions in Dairy Cattle. Front Vet Sci. 10:90-97. Krol, H. Mensen Turven. 1985. Afstudeerscriptie doctoraal geschiedenis, Utrecht Universiteit. 
de Kruif A. 2001. Did vaccination with an infectious bovine rhinotracheitis (IBR) marker vaccine on thirteen cattle farms give rise to chronic wasting among dairy cattle?. Tijdschr Diergeneeskd. 126:166-173.

Lievaart-Peterson, K., Luttikholt, S., Peperkamp, K., Van den Brom, R., Vellema, P. 2015. Schmallenberg disease in sheep or goats: Past, present and future. Vet Microbiol. 181:147-153.

Lu, Z., Schukken, Y.H., Smith, R.L., Grohn, Y.T. 2010. Stochastic simulations of a multi-group compartmental model for Johne's disease on US dairy herds with test-based culling intervention. J Theor Biol. 264:1190-1201.

Mitchell, R.M., Whitlock, R.H., Gröhn, Y.T., Schukken, Y.H. 2015. Back to the real world: connecting models with data. Prev Vet Med. 118:215-225.

Morens, D.M. Holmes, E.C., Davis, A.S., Taubenberger, J.K. 2011. Global rinderpest eradication: lessons learned and why humans should celebrate too. J. Infect. Dis 204: 502-505.

van Nes, A. 2001. Mathematical modelling of pseudorabies virus (syn. Aujeszky's disease virus) outbreaks aids eradication programmes: a review. Vet Q. 23:21-26.

Nielsen, T.D., Nielsen, L.R., Toft, N., Houe, H. 2010. Association between bulk-tank milk Salmonella antibody level and high calf mortality in Danish dairy herds. J Dairy Sci. 93:304-310.

Oikonomou, G., Bicalho, M.L., Meira, E., Rossi, R.E., Foditsch, C., Machado, V.S., Teixeira, A.G., Santisteban, C., Schukken, Y.H., Bicalho, R.C. 2014. Microbiota of cow's milk; distinguishing healthy, sub-clinically and clinically diseased quarters. PLoS One. 9:e85904.

Peperkamp, N.H., Luttikholt, S.J., Dijkman, R., Vos, J.H., Junker, K., Greijdanus, S., Roumen, M.P., van Garderen, E., Meertens, N., van Maanen, C., Lievaart, K., van Wuyckhuise, L., Wouda, W. 2015. Ovine and Bovine Congenital Abnormalities Associated With Intrauterine Infection With Schmallenberg Virus. Vet Pathol. 52:1057-1066.

Pomeroy, B., Sipka, A., Klaessig, S., Schukken, Y.H. 2016. Longitudinal characterization of bovine monocyte-derived dendritic cells from mid-gestation into subsequent lactation reveals nadir in phenotypic maturation and macrophage-like cytokine profile in late gestation. J Reprod Immunol. 118:1-8.

Pomeroy, B., Sipka, A., Klaessig, S., Schukken, Y.H. 2015. Monocyte-derived dendritic cells from late gestation cows have an impaired ability to mature in response to E. coli stimulation in a receptor and cytokine-mediated fashion. Vet Immunol Immunopathol. 167:22-29.

Quesnell, R.R., Klaessig, S., Watts, J.L., Schukken, Y.H. 2012. Bovine intramammary Escherichia coli challenge infections in late gestation demonstrate a dominant antiinflammatory immunological response. J Dairy Sci. 95:117-126.

Roest, H.I., Tilburg, J.J., van der Hoek, W., Vellema, P., van Zijderveld, F.G., Klaassen, 
C.H., Raoult, D. 2011. The Q fever epidemic in The Netherlands: history, onset, response and reflection. Epidemiol Infect. 139:1-12.

Santman-Berends, I.M., Brouwer-Middelesch, H., Van Wuijckhuise, L., de BontSmolenaars, A.J., Van Schaik, G. 2016. Surveillance of cattle health in the Netherlands: Monitoring trends and developments using routinely collected cattle census data. Prev Vet Med. 134:103-112.

Scheffer, M., Carpenter, S., Foley, J.A., Folke, C., Walker, B. 2001. Catastrophic shifts in ecosystems. Nature. 413:591-596.

Scherpenzeel CG, den Uijl IE, van Schaik G, Olde Riekerink RG, Keurentjes JM, Lam TJ. 2014. Evaluation of the use of dry cow antibiotics in low somatic cell count cows. J Dairy Sci. 97:3606-3614.

Schukken, Y.H., Whitlock, R.H., Wolfgang, D., Grohn, Y., Beaver, A., VanKessel, J., Zurakowski, M., Mitchell, R. 2015. 65 Longitudinal data collection of

Mycobacterium avium subspecies paratuberculosis infections in dairy herds: the value of precise field data. Vet Res. 46:65-75.

Senne, D.A., King, D.J., Kapczynski, D.R. 2004. Control of Newcastle disease by vaccination. Dev. Biol. 119:165-170.

Sipka, A., Pomeroy, B., Klaessig, S., Schukken, Y.H. 2016. Bovine natural killer cells are present in Escherichia coli infected mammary gland tissue and show antimicrobial activity in vitro. Comp Immunol Microbiol Infect Dis. 48:54-6o.

Stegeman, A., Elbers, A., de Smit, H., Moser, H., Smak, J., Pluimers, F. 2000. The 1997-1998 epidemic of classical swine fever in the Netherlands. Vet Microbiol 73:183-96.

Stegeman, A., Bouma, A., Elbers, A.R., de Jong, M.C., Nodelijk, G., de Klerk, F., Koch, G., van Boven, M. 2004. Avian influenza A virus $\left(\mathrm{H}_{7} \mathrm{~N}_{7}\right)$ epidemic in The Netherlands in 2003: course of the epidemic and effectiveness of control measures. J Infect Dis. 190:2088-2095.

Sundberg, A. 2015. Spiritual and Secular Therapies: Combatting Cattle Plague during an Era of Disaster. PhD thesis, University of Kansas.

Thomann, B., Falzon, L.C., Bertoni, G., Vogt, H.R., Schüpbach-Regula, G., Magouras, I. 2017. A census to determine the prevalence and risk factors for caprine arthritis-encephalitis virus and visna/maedi virus in the Swiss goat population. Prev Vet Med. 137:52-58.

Uiterwijk, M., De Rosa, M., Friesema, I., Valkenburgh, S., Roest, H.J., van Pelt, W., van den Kerkhof, H., van der Giessen, J. And K. Maassen. 2016. Staat van Zoonosen. RIVM rapport 2016-0139.

Veldhuis, A., Brouwer-Middelesch, H., Marceau, A., Madouasse, A., Van der Stede, Y., Fourichon, C., Welby, S., Wever, P., van Schaik, G. 2016. Application of syndromic surveillance on routinely collected cattle reproduction and milk production data for the early detection of outbreaks of Bluetongue and 
Schmallenberg viruses. Prev Vet Med. 124:15-24.

van Wuijckhuise, L., Frankena, K., van Oijen, M.A., Meijer, L. 2001. Analysis of symptoms associated with bovine herpesvirus 1 vaccination. Tijdschr Diergeneeskd. 126:173-180.

Ypma, R.J., Bataille, A.M., Stegeman, A., Koch, G., Wallinga, J., van Ballegooijen, W.M. 2012. Unravelling transmission trees of infectious diseases by combining genetic and epidemiological data. Proc Biol Sci. 279: 444-450. 



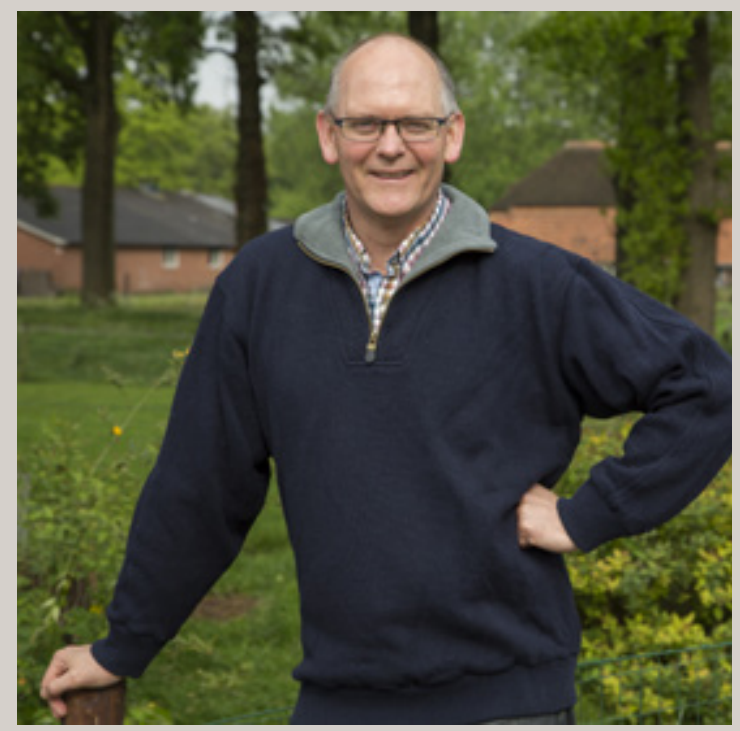

Prof.dr Ynte H. Schukken

'This inaugural lecture will take you on a tour through the progress, problems and perspectives in farm animal health. Transparency of the Dutch animal industries with regard to the health of animals is unsurpassed in the world. The Netherlands has a well-developed animal health surveillance system in place. However, infectious diseases in farm animals will continuously evolve. For that reason, farm animal health is never 'finished'. It is therefore essential to continue innovative research and to maintain a precise understanding of disease dynamics in animal and human populations.' 